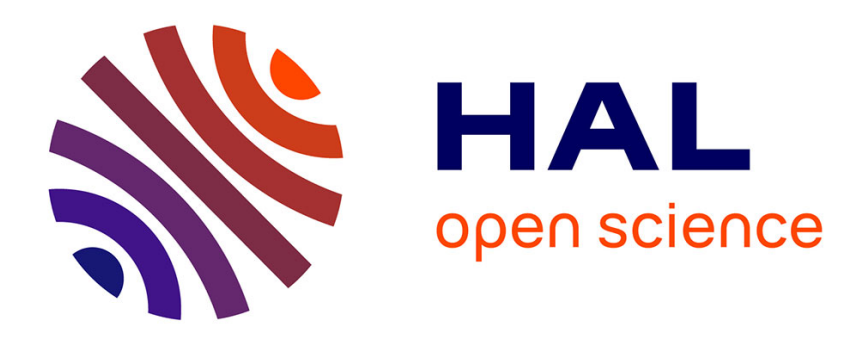

\title{
Enhanced recovery after hepatectomy: a systematic review
}

\author{
Pauline Rouxel, Hélène Beloeil
}

\section{To cite this version:}

Pauline Rouxel, Hélène Beloeil. Enhanced recovery after hepatectomy: a systematic review. Anaesthesia Critical Care \& Pain Medicine, 2019, 38 (1), pp.29-34. 10.1016/j.accpm.2018.05.003 . hal01807759

\section{HAL Id: hal-01807759 \\ https://hal-univ-rennes1.archives-ouvertes.fr/hal-01807759}

Submitted on 4 Jul 2018

HAL is a multi-disciplinary open access archive for the deposit and dissemination of scientific research documents, whether they are published or not. The documents may come from teaching and research institutions in France or abroad, or from public or private research centers.
L'archive ouverte pluridisciplinaire HAL, est destinée au dépôt et à la diffusion de documents scientifiques de niveau recherche, publiés ou non, émanant des établissements d'enseignement et de recherche français ou étrangers, des laboratoires publics ou privés. 


\title{
Enhanced recovery after hepatectomy: a systematic review
}

\author{
Pauline Rouxel . Helene Beloeil ${ }^{1}$
}

1 Department of Anaesthesiology and Critical Care Medicine, CHU de Rennes, Université Rennes, Inserm NumeCan, CIC 1414, Rennes, FRANCE

\section{Corresponding author:}

Prof Helene Beloeil

Pole Anesthésie-réanimation, CHU de Rennes, Université Rennes, Inserm NumeCan, CIC 1414,

2 avenue Henri le Guilloux

35033 Rennes Cedex, FRANCE

Tel: 33 (0)2 992824 22, Fax: 33 (0)2 99282421

E-mail: helene.beloeil@chu-rennes.fr

\section{Conflicts of interest: none}

Funding: Funding was solely institutional.

Short title: ERP after hepatectomy 
Key words: ERP, hepatectomy

\section{Enhanced recovery after hepatectomy: a systematic review}

Page 2 of 36 


\section{Conflicts of interest: none}

Funding: Funding was solely institutional.

Short title: ERP after hepatectomy

Key words: ERP, hepatectomy, liver, fast-track

\section{Abstract}

Background: Hepatectomy is a surgery with high postoperative complication rates. Enhanced recovery after surgery (ERAS) clinical pathways in liver surgery have been studied and may become a standard of care. However, few specific recommendations have been published so far.

Objective: The aim of this study was to assess the efficacy and safety of the enhanced recovery program in liver surgery.

Methods: Randomised controlled trials (RCTs) comparing ERAS group with traditional care published between 2007 and 2017 were included in this review. The outcomes were length of stay (LOS), complications, mortality and readmission rate for all liver surgeries except transplantation.

Results: Five hundred and twenty-four patients randomised in 4 RCTs were analysed. Two hundred and fifty-four patients were in ERAS group and 270 patients in traditional care (TC) group. Two studies compared cares in laparoscopic surgery and 2 in open surgery. Postoperative LoS was significantly lower in the ERAS group whereas readmission and mortality rate were similar. ERAS group had also significant lower complication rate in 2 studies of the 4 . The complication rate in the 2 other studies was similar. 
Conclusion: ERAS protocols in liver surgery appeared to be safe and effective. Recent recommendations from the ERAS group in liver surgery are the only ones published so far. Other studies evaluating ERAS components in liver surgery and recommendations from scientific societies are needed to spread this clinical care pathway. 


\section{Introduction}

Fast-track surgery was introduced in 1997 by Kehlet [1] and has been widely applied since. The primary goal of this clinical pathway was to improve postoperative patient outcomes and decrease hospitalisation costs. In fact, enhanced recovery or fast-track programs have been shown to be safe, effective and mostly beneficial for the patient. Indeed, Wu et al [2] reported lower complication rate in ERAS clinical pathways. Colorectal surgery has been the most studied in ERAS programs. Thereby, recent recommendations for enhanced recovery in colorectal surgery have been established by the French Society of abdominal Surgery (SFCD) and the French society of Anaesthesia and Intensive Care Medicine (SFAR)[3]. The following items are associated with a benefit preoperative counselling and feeding, carbohydrate intake before surgery, immunonutrition before colorectal cancer surgery, goal-directed intraoperative fluid management laparoscopic procedure, multi-modal analgesia, early ambulation and feeding and minimal drain policy. Nowadays, an increasing number of centres tries to apply this clinical pathway to others surgeries like cardiovascular [4] and orthopaedic [5] surgeries. Items of ERAS in colorectal surgery have been applied to hepatic surgery. However, liver surgery has its own complications and high mortality-morbidity rate (15\% to 48\%) $[6,7]$. Therefore, it is not clear if ERAS program in liver surgery is safe and effective.

The aim of this review was to assess the safety and efficacy of ERAS protocols versus traditional care by comparing length of stay in hospital (LoS), complications, mortality and readmission rates for patients after liver surgery. We hypothesized that ERAS protocols are relevant and thus can be used on a daily basis. 


\section{Methods}

We performed a systematic review of literature according to PRISMA guidelines (Preferred Reporting Items for Systematic reviews and MetaAnalyses).

\section{Search strategy and study selection}

We searched the Cochrane Central Register of Controlled Trials, Medline and completed clinical trials in Clinicaltrials.gov from January 2007 to November 2017. And we restricted the search to English language. The search terms were (fast-track OR fast track OR enhanced recovery OR ERAS OR rehabilitation) AND (hepatectomy OR hepatectomies OR liver resection OR liver resections OR hepatic resection OR hepatic resections OR liver surgery OR liver surgeries) NOT transplantation. We ensure that terms associated individually could give the same result. Relevance was established first on the title then the abstract and on full-texts if information was not found in the abstract. All relevant articles were exported to Zotero $^{\circledR}$ (reference management Software).

\section{Inclusion and exclusion criteria}

The criteria for eligibility were (1) full-text RCTs (randomised clinical trials) which: (2) compared traditional care versus enhanced recovery (3) in liver surgery (laparoscopic or open) and (4) considered at least one outcome among: length of stay (LoS), morbidity, mortality and readmission rates. We did not reach study authors to identify additional studies. Exclusion criterion were (1) prospective or retrospective cohort study or case-control study, 
(2) studies considering transplantation surgery, (3) studies not comparing ERAS care versus traditional care, (4) studies consisted of unpublished data with only the abstract. Guidelines, reviews and meta-analysis were considered apart.

\section{Data extraction}

Year of study publication, authors, title, study characteristics, type of surgery, number of patients and their characteristics (age, ASA score, gender), ERAS protocol/items, length of stay, readmission, morbidity and mortality rates, primary and secondary outcomes and methodological quality (JADAD score) were extracted in a spread sheet. Two members reviewed data of relevant studies.

\section{Quality assessment}

Quality assessment was performed using the JADAD composite scale (1-5), which attributes 1 point for blinding, appropriate method of blinding, randomisation, appropriate method of randomisation and description of outputs and withdrawals while attribute -1 point if blinding is inappropriate or if randomisation is inappropriate. 


\section{Results}

\section{Literature selection}

Initial search found 388 articles. There was no duplicate. After reviewing titles and abstracts, 323 articles did not concern liver surgery or enhanced recovery. Of the 65 articles left, 34 were not RCTs, 23 were review and meta-analyses, 1 was recommendations/guidelines and 3 were RCTs with no traditional care controlled group. Finally, we reviewed 4 articles. The PRISMA diagram is shown Legend of the figures:

Figure 1: PRISMA flow chart

Table I: JADAD composite scale score for each study. Points attribution: 1 point for blinding, appropriate method of blinding, randomization, appropriate method of randomization and description of outputs and withdrawals while attribute -1 point if blinding was inappropriate or if randomization was inappropriate

Table II: Characteristics of the studies: ASA: American Society of Anesthesiologists, ERAS: Enhanced Recovery After Surgery, TC: Traditional Care, HCC: hepatocellular carcinoma.

Table III: Summary of ERAS components. ERAS: Enhanced Recovery After Surgery, NA: Not Available, i.v.: intra venous, ICU: Intensive Care Unit, PCIA: Patient-Controlled Intravenous Analgesia.

component present in the study.

Table IV: Results of the studies 
We wish to confirm that there are no known conflicts of interest associated with this publication and there has been no significant financial support for this work that could have influenced its outcome.

We confirm that the manuscript has been read and approved by all named authors and that there are no other persons who satisfied the criteria for authorship but are not listed. We further confirm that the order of authors listed in the manuscript has been approved by all of us.

We confirm that we have given due consideration to the protection of intellectual property associated with this work and that there are no impediments to publication, including the timing of publication, with respect to intellectual property. In so doing we confirm that we have followed the regulations of our institutions concerning intellectual property.

We further confirm that any aspect of the work covered in this manuscript that has involved either experimental animals or human patients has been conducted with the ethical approval of all relevant bodies and that such approvals are acknowledged within the manuscript.

We understand that the Corresponding Author is the sole contact for the Editorial process (including Editorial Manager and direct communications with the office). He/she is responsible for communicating with the other authors about progress, submissions of revisions and final approval of proofs. We confirm that we have provided a current, correct email address which is accessible by the Corresponding Author and which has been configured to accept email from (helene.beloeil@chu-rennes.fr)

Signed by all authors as follows:

Helene Beloeil

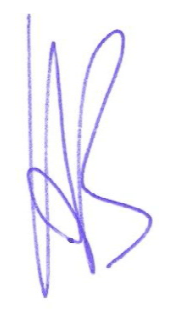

Pauline Rouxel 


\section{EX TABLE I}

\begin{tabular}{|c|c|c|c|c|c|c|c|c|c|c|c|c|}
\hline \multirow[t]{2}{*}{ Author } & \multirow[t]{2}{*}{ Year } & \multirow[t]{2}{*}{ JADAD } & \multicolumn{2}{|c|}{$\begin{array}{c}\text { Sample size } \\
(n)\end{array}$} & \multicolumn{2}{|c|}{$\begin{array}{c}\text { Age (years) } \\
\text { Mean } \pm S D(\text { except *) }\end{array}$} & \multicolumn{2}{|c|}{$\begin{array}{c}\text { Gender } M / F \\
(n)\end{array}$} & \multicolumn{2}{|c|}{$\underset{(n)}{\operatorname{ASA} \mathbf{I}, \mathbf{I I}, \mathbf{I I I}}$} & \multirow[t]{2}{*}{$\begin{array}{l}\text { Type of } \\
\text { surgery }\end{array}$} & \multirow{2}{*}{$\begin{array}{c}\begin{array}{c}\text { Patholo } \\
\text { / ber }\end{array} \\
\text { ERAS }\end{array}$} \\
\hline & & & ERAS & $\mathbf{T C}$ & ERAS & TC & ERAS & TC & ERAS & TC & & \\
\hline He, F. (10) & 2015 & 3 & 48 & 38 & $56.3 \pm 16.3$ & $60.4 \pm 20.7$ & $22 / 26$ & $\begin{array}{c}18 / \\
20\end{array}$ & $10,26,3$ & $12,24,2$ & Laparoscopic & $31 / 17$ \\
\hline Jones, C. (9) & 2013 & 3 & 46 & 45 & $\begin{array}{c}64(27- \\
83)^{*}\end{array}$ & $67(27-84)^{*}$ & $31 / 15$ & $\begin{array}{l}23 / \\
22\end{array}$ & $0,43,3$ & $2,38,5$ & Open & $45 / 1$ \\
\hline Liang, X. (8) & 2016 & 2 & 80 & 107 & $53.4 \pm 13.5$ & $55.5 \pm 12.8$ & 37 / 43 & $\begin{array}{l}50 / \\
57\end{array}$ & $35,45, \mathrm{NC}$ & $49,58, \mathrm{NC}$ & Laparoscopic & $51 / 29$ \\
\hline Ni, C.Y. (11) & 2013 & 2 & 80 & 80 & $48.4 \pm 15.6$ & $50.1 \pm 21.8$ & 66 / 14 & $\begin{array}{c}59 / \\
21\end{array}$ & $76,4, \mathrm{NC}$ & $78,2, \mathrm{NC}$ & Open & $80 / 0$ \\
\hline
\end{tabular}

* Median (interquartile range)

NEW TABLE I BECOMING TABLE II 


\section{Characteristics of the studies}

\begin{tabular}{|c|c|c|c|c|c|c|c|c|c|c|c|c|c|c|}
\hline \multirow[t]{2}{*}{ Author } & \multirow[t]{2}{*}{ Year } & \multicolumn{2}{|c|}{$\begin{array}{l}\text { Sample } \\
\text { size }\end{array}$} & \multicolumn{3}{|c|}{$\begin{array}{c}\text { Age (years) } \\
\text { Mean } \pm \text { SD (except *) }\end{array}$} & \multicolumn{4}{|c|}{$\begin{array}{c}\text { Gender M/F } \\
n(\%)\end{array}$} & \multicolumn{4}{|c|}{$\begin{array}{c}\text { ASA I, II, III } \\
n(\%)\end{array}$} \\
\hline & & ERAS & $\mathrm{TC}$ & ERA & & $\mathrm{TC}$ & ERAS & & TC & & ERAS & & & TC \\
\hline $\mathrm{He}, \mathrm{F} .(10)$ & 2015 & 48 & 38 & $56.3 \pm$ & 16.3 & $60.4 \pm 20.7$ & $22(46 \%) / 26$ & $(54 \%)$ & $18(47 \%) / 2$ & $53 \%)$ & $10(21 \%), 26(54 \%$ & $2(4 \%)$ & $12(32 \%), 2$ & $24(63 \%), 2(5 \%)$ \\
\hline Jones, C. (9) & 2013 & 46 & 45 & $64(27-$ & $83)^{*}$ & $67(27-84)^{*}$ & $22(48 \%) / 15$ & $(33 \%)$ & $23(51 \%) / 2$ & $(49 \%)$ & $0,43(93 \%), 3$ & $7 \%)$ & $2(4,5 \%), 38$ & $(84,5 \%), 5(11 \%$ \\
\hline Liang, X. (8) & 2016 & 80 & 107 & $53.4 \pm$ & 13.5 & $55.5 \pm 12.8$ & $22(28 \%) / 43$ & $(54 \%)$ & $50(47 \%) / 5$ & $(53 \%)$ & $35(44 \%), 45(5$ & $\%), 0$ & $49(46 \%$ & $58(54 \%), 0$ \\
\hline Ni, C.Y. (11) & 2013 & 80 & 80 & $48.4 \pm$ & 15.6 & $50.1 \pm 21.8$ & $22(27,5 \%) / 14$ & $(17,5 \%)$ & $59(74 \%) / 2$ & $(26 \%)$ & $76(95 \%), 4(5$ & ), 0 & $78(97,5)$ & $\%), 2(2,5 \%), 0$ \\
\hline \multirow[t]{2}{*}{ Author } & \multirow{2}{*}{\multicolumn{2}{|c|}{$\begin{array}{l}\text { Type of } \\
\text { surgery }\end{array}$}} & \multicolumn{4}{|c|}{ Perioperative blood loss $(m L)$} & \multicolumn{3}{|c|}{$\begin{array}{l}\text { Pathology malign / benign } \\
\mathrm{n}(\%)\end{array}$} & \multirow{2}{*}{\multicolumn{2}{|c|}{$\begin{array}{l}\text { Reasons for liver } \\
\text { resection (malign } \\
\text { pathologies) }\end{array}$}} & \multicolumn{3}{|c|}{$\begin{array}{l}\text { Extent of liver resection } \\
\text { major / minor }{ }^{* *}, \mathrm{n}(\%)\end{array}$} \\
\hline & & & \multicolumn{2}{|c|}{ ERAS } & \multicolumn{2}{|r|}{ TC } & ERAS & \multicolumn{2}{|r|}{ TC } & & & \multicolumn{2}{|c|}{ ERAS } & TC \\
\hline $\mathrm{He}, \mathrm{F} .(10)$ & \multicolumn{2}{|c|}{ Laparoscopic } & \multicolumn{2}{|c|}{$350 \pm 170$} & \multicolumn{2}{|c|}{$338 \pm 190$} & $31(65 \%) / 17(35 \%)$ & \multicolumn{2}{|c|}{$24(63 \%) / 14(37 \%)$} & \multicolumn{2}{|c|}{ HCC, Colorectal Mets } & \multicolumn{2}{|c|}{$0 / 48(100 \%)$} & $0 / 38(100 \%)$ \\
\hline Jones, C. (9) & \multicolumn{2}{|c|}{ Open } & \multicolumn{2}{|c|}{$350(174-900)^{*}$} & \multicolumn{2}{|c|}{$340(150-645)^{*}$} & $45(98 \%) / 1(2 \%)$ & \multicolumn{2}{|c|}{$36(80 \%) / 9(20 \%)$} & \multicolumn{2}{|c|}{ Colorectal Mets, Other Mets } & \multicolumn{2}{|c|}{$21(46 \%) / 25(54 \%)$} & $12(27 \%) / 33(7:$ \\
\hline Liang, $X .(8)$ & \multicolumn{2}{|c|}{ Laparoscopic } & \multicolumn{2}{|c|}{$268.2 \pm 416.0$} & \multicolumn{2}{|c|}{$328.0 \pm 426.2$} & $51(64 \%) / 29(36 \%)$ & $55(51 \%$ & ) / $52(49 \%)$ & \multicolumn{2}{|c|}{$\begin{array}{c}\text { HCC, HCC Mets, } \\
\text { Cholangiocarcinoma }\end{array}$} & \multicolumn{2}{|c|}{$17(21 \%) / 63(79 \%)$} & $29(27 \%) / 78(7$ \\
\hline Ni, C.Y. (11) & \multicolumn{2}{|c|}{ Open } & \multicolumn{2}{|c|}{$313.4 \pm 223.9$} & \multicolumn{2}{|c|}{$358.2 \pm 311.7$} & $80(100 \%) / 0$ & $80(1$ & $100 \%) / 0$ & $\mathrm{HCC}$, & olangiocarcinoma & $73(91$ & $\%) / 7(9 \%)$ & $69(86 \%) / 11(1$ \\
\hline
\end{tabular}

- Median (interquartile range)

** Major resection: $\geq 3$ segments 
Table I: JADAD composite scale score for each study

\section{JADAD Score}

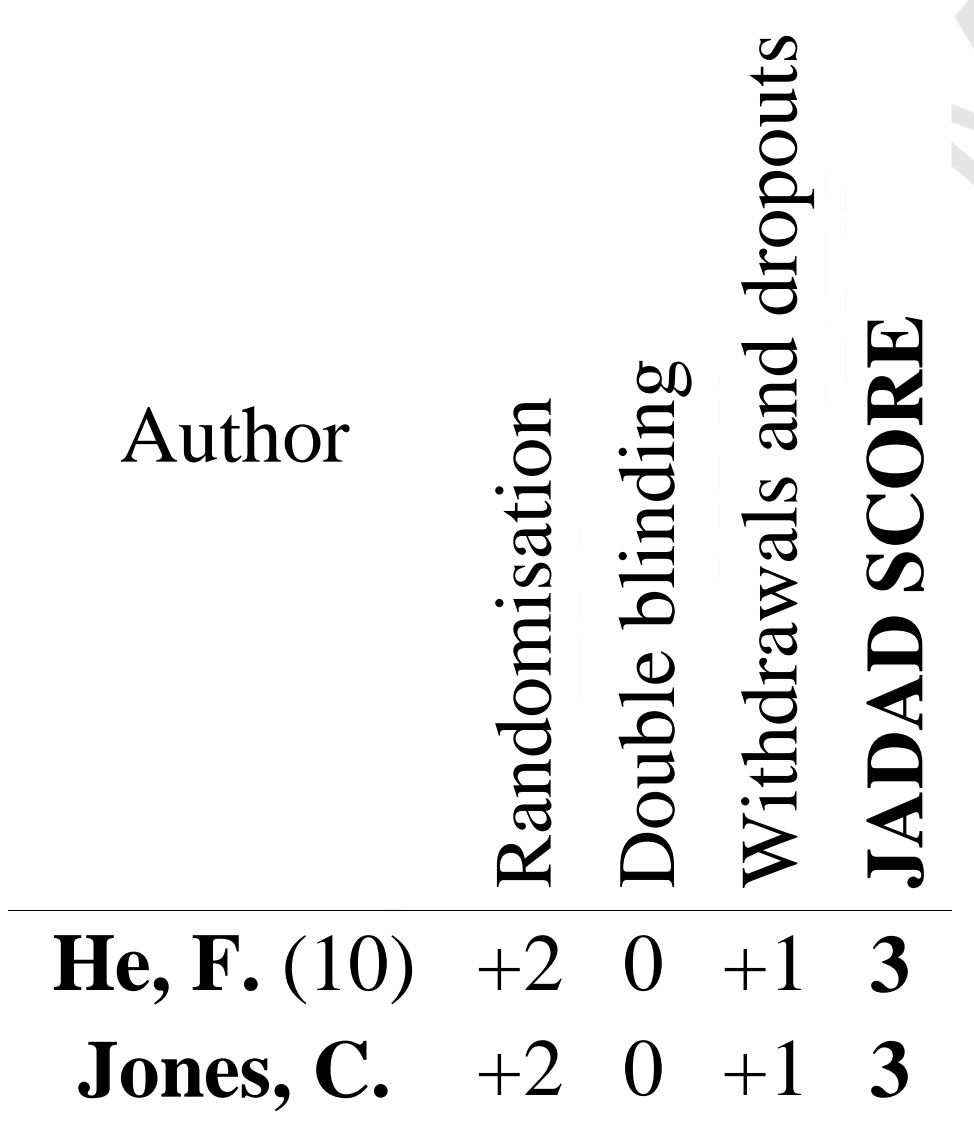


(9)

\section{Liang, $X$.}

(8)

Ni, C.Y.

(11) $\begin{array}{llll}+1 & 0 & 0 & 1\end{array}$

$\begin{array}{llll}+2 & 0 & +1 & 3\end{array}$

\begin{tabular}{|c|c|c|c|c|}
\hline & $\begin{array}{l}\text { He, F. } 2015 \\
(10)\end{array}$ & Jones, C. 2013 (9) & $\begin{array}{c}\text { Liang, X. } 2016 \\
(8)\end{array}$ & Ni, C.Y. 2013 (11) \\
\hline \multicolumn{5}{|l|}{ Preoperative } \\
\hline \multicolumn{5}{|l|}{ Preoperative education or exercise } \\
\hline \multicolumn{5}{|l|}{ Avoid bowel preparation } \\
\hline Avoid preanesthetic medications & $N A$ & & $N A$ & \\
\hline \multicolumn{5}{|l|}{ Carbohydrate drinks up to $2 h$ before } \\
\hline \multicolumn{5}{|l|}{ surgery. } \\
\hline Minimal preoperative fasting (2h) & & $N A$ & $N A$ & $N A$ \\
\hline \multicolumn{5}{|l|}{ Perioperative } \\
\hline \multicolumn{5}{|l|}{ Antibiotic prophylaxis } \\
\hline \multicolumn{5}{|l|}{ Epidural analgesia } \\
\hline \multicolumn{5}{|l|}{ Short-acting i.v. anesthetic agent } \\
\hline \multicolumn{5}{|l|}{ Prevention of hypothermia } \\
\hline \multicolumn{5}{|l|}{ Avoidance of excessive i.v. fluids } \\
\hline \multicolumn{5}{|l|}{ No routine drainage of the peritoneal } \\
\hline No nasogastric tube or early removal & & & & \\
\hline
\end{tabular}


after surgery

\section{Postoperative}

Not sent routinely to the ICU

Early removal of urinary catheter (within the 1st 24h)

Early oral intake

Early mobilization

Early discontinuation of i.v. fluids

Early restoration of normal diet

Glucose control

Nausea and vomiting prophylaxis

Multimodal analgesia

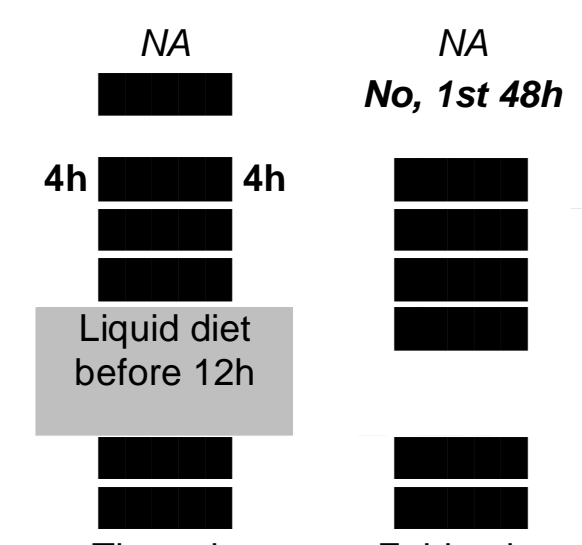

Thoracic epidural
Epidural +

(1g paracetamol + tramadol 50-

$100 \mathrm{mg} / 6 \mathrm{~h}$

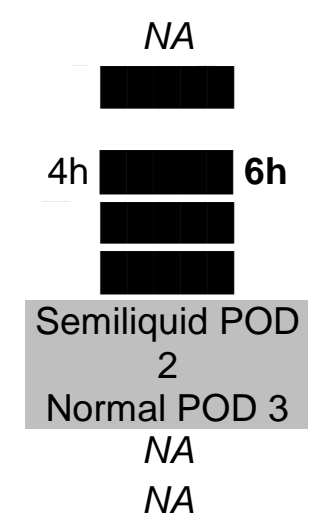

Trocar incision

analgesia + PCIA + 40mg transdermal patch

ParecoxibNa

$/ 12 \mathrm{~h}+/-50 \mathrm{mg}$

tramadol

NA

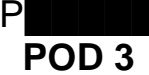

$N A$

$N A$

Epidural or

\section{Discharge criteria}

Normal or decreasing serum bilirubin

Good pain control with oral analgesia only

Tolerance of solid food

No i.v. fluids

Mobile independently or at the preoperative level

Willingness to go home

Normal body temperature

No incision infection
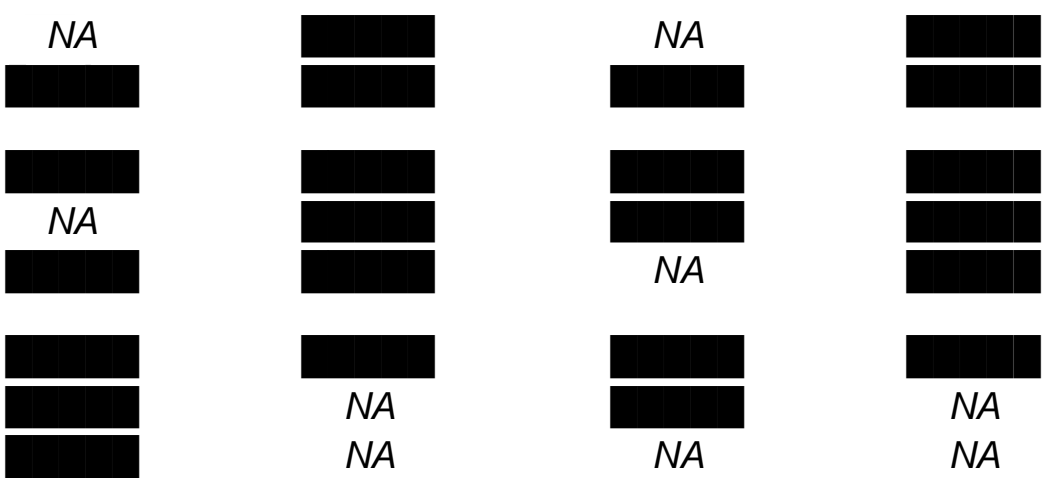

(n)


EX TABLE III 


\begin{tabular}{|c|c|c|c|c|c|c|c|c|c|}
\hline \multirow[t]{2}{*}{ Author } & \multirow[t]{2}{*}{ Year } & \multirow[t]{2}{*}{$\begin{array}{l}\text { Type } \\
\text { of } \\
\text { cases }\end{array}$} & \multicolumn{2}{|c|}{$\begin{array}{l}\text { Nb. of } \\
\text { patients } \\
(n)\end{array}$} & \multirow[t]{2}{*}{ Study endpoints } & \multirow{2}{*}{$\begin{array}{l}\text { Complication } \\
\text { \& morbidity } \\
\text { ERAS / TC }\end{array}$} & \multirow{2}{*}{$\begin{array}{c}\text { Postoperative } \\
\text { length of stay } \\
\text { (days) } \\
\begin{array}{c}\text { Median (interquartile } \\
\text { range) }\end{array} \\
\text { ERAS / TC }\end{array}$} & \multirow{2}{*}{$\begin{array}{l}\text { Readmission } \\
\qquad(n) \\
\text { ERAS / TC }\end{array}$} & \multirow{2}{*}{$\begin{array}{r}\text { Mor } \\
\text { ER } \\
\mathbf{T}\end{array}$} \\
\hline & & & $\begin{array}{c}\text { ERA } \\
\mathbf{S}\end{array}$ & $\mathbf{T C}$ & & & & & \\
\hline He, F. (10) & 2015 & $\mathrm{RCT}$ & 48 & 38 & $\begin{array}{l}\text { Primary: quality of life ; LoS } \\
\text { Secondary: } \% \text { of readmission ; mortality ; } \\
\text { functional recovery ; complication ; hospital } \\
\text { costs ; conversions ; blood loss }\end{array}$ & $\begin{array}{c}7(15 \%) / 6(16 \%) \\
p=0.88\end{array}$ & $\begin{array}{c}6(4-8) / 10(7-15) \\
p=0.04\end{array}$ & $\begin{array}{l}1 / 1 \\
p=1\end{array}$ & $\begin{array}{c}0 \\
p=\end{array}$ \\
\hline $\begin{array}{c}\text { Jones, C. } \\
(9)\end{array}$ & 2013 & $\mathrm{RCT}$ & 46 & 45 & $\begin{array}{l}\text { Primary: LoS } \\
\text { Secondary: Pain score ; morbidity ; } \\
\text { mortality ( } 30 \text { days follow-up) ; volume of } \\
\text { IV fluids ; time to return of : bowel sounds, } \\
\text { flatus, full diet, bowel opening and } \\
\text { mobilization }\end{array}$ & $\begin{array}{l}17 \% / 31 \% \\
p=0.126\end{array}$ & $\begin{array}{c}4(3-5) / 7(6-8) \\
p<0.001\end{array}$ & $\begin{array}{c}2 / 0 \\
p=0.153\end{array}$ & $p=$ \\
\hline$\underset{(8)}{\text { Liang, } \mathbf{X} .}$ & 2016 & $\mathrm{RCT}$ & 80 & 107 & $\begin{array}{l}\text { Primary: LoS ; hospitalization cost } \\
\text { Secondary: resumption of oral intake ; pain } \\
\text { score ; readmissions ; complications }\end{array}$ & $\begin{array}{c}18(22 \%) / 47 \\
(44 \%) \\
p=\mathbf{0 . 0 0 2}\end{array}$ & $\begin{array}{c}6 \pm 2.6 / 9.9 \pm 5.9 \\
\boldsymbol{p}<0.001\end{array}$ & $\begin{array}{c}3 / 5 \\
p=0.6\end{array}$ & $\begin{array}{c}0 \\
p=\end{array}$ \\
\hline $\begin{array}{l}\text { Ni, C.Y. } \\
\quad(11)\end{array}$ & 2013 & $\mathrm{RCT}$ & 80 & 80 & $\begin{array}{l}\text { Primary: complication rate } \\
\text { Secondary: C-reactive protein level ; LoS } \\
\text { liver functional status on POD } 5 ; \text { general } \\
\text { comfort questionnaire measures }\end{array}$ & $\begin{array}{c}24(30 \%) / 37 \\
(46 \%) \\
p=0.03\end{array}$ & $\begin{array}{c}6.9 \pm 2.8 / 8.0 \pm 3.7 \\
\boldsymbol{p}=\mathbf{0 . 0 1 8}\end{array}$ & $\mathrm{NC}$ & $\Lambda$ \\
\hline
\end{tabular}




\section{Results of the studies}

\begin{tabular}{|c|c|c|c|c|c|c|c|c|c|}
\hline \multirow{3}{*}{ Author } & \multirow{3}{*}{ Year } & \multirow{3}{*}{$\begin{array}{l}\text { Type } \\
\text { of } \\
\text { cases }\end{array}$} & \multirow{2}{*}{\multicolumn{2}{|c|}{$\begin{array}{l}\text { Nb. of } \\
\text { patients } \\
(n)\end{array}$}} & \multirow{3}{*}{ Study endpoints } & \multicolumn{2}{|c|}{ Complications } & \multirow{3}{*}{$\begin{array}{c}\text { Postoperative } \\
\text { length of stay } \\
\text { (days) } \\
\begin{array}{c}\text { Median (interquartile } \\
\text { range) }\end{array} \\
\text { ERAS / TC }\end{array}$} & \multirow{3}{*}{$\begin{array}{l}\text { Readmissiol } \\
\qquad(n) \\
\text { ERAS / TC }\end{array}$} \\
\hline & & & & & & \multicolumn{2}{|c|}{$\underset{\text { to } V}{\text { Grade I }}$} & & \\
\hline & & & ERAS & TC & & ERAS / TC & ERAS / TC & & \\
\hline $\begin{array}{c}\mathbf{H e}, \mathbf{F} . \\
(10)\end{array}$ & 2015 & $\mathrm{RCT}$ & 48 & 38 & $\begin{array}{l}\text { Primary: quality of life ; LoS } \\
\text { Secondary: \% of readmission ; } \\
\text { mortality ; functional recovery ; } \\
\text { complication ; hospital costs ; } \\
\text { conversions ; blood loss }\end{array}$ & $\begin{array}{l}4(8 \%) / 2 \\
(5 \%) \\
p=\mathrm{NC}\end{array}$ & $\begin{array}{l}3(6 \%) / 4 \\
(10.5 \%) \\
p=\mathrm{NC}\end{array}$ & $\begin{array}{c}6(4-8) / 10(7- \\
15) \\
p=0.04\end{array}$ & $\begin{array}{l}1 / 1 \\
p=1\end{array}$ \\
\hline $\begin{array}{c}\text { Jones, C. } \\
(9)\end{array}$ & 2013 & RCT & 46 & 45 & $\begin{array}{l}\text { Primary: LoS } \\
\text { Secondary: Pain score ; morbidity ; } \\
\text { mortality ( } 30 \text { days follow-up) ; volume } \\
\text { of IV fluids ; time to return of : bowel } \\
\text { sounds, flatus, full diet, bowel opening } \\
\text { and mobilization }\end{array}$ & $\begin{array}{c}2(4 \%) / 4 \\
(9 \%) \\
p=N C\end{array}$ & $\begin{array}{c}12(26 \%) / \\
24(53 \%) \\
p=N C\end{array}$ & $\begin{array}{c}4(3-5) / 7(6-8) \\
p<0.001\end{array}$ & $\begin{array}{c}2 / 0 \\
p=0.153\end{array}$ \\
\hline $\begin{array}{l}\text { Liang, } \\
\text { X. (8) }\end{array}$ & 2016 & $\mathrm{RCT}$ & 80 & 107 & $\begin{array}{l}\text { Primary: LoS ; hospitalization cost } \\
\text { Secondary: resumption of oral intake } \\
\text { pain score ; readmissions ; } \\
\text { complications }\end{array}$ & $\begin{array}{c}5(6 \%) / 14 \\
(13 \%) \\
p=N C\end{array}$ & $\begin{array}{c}13(16 \%) / 33 \\
(31 \%) \\
p=0.02\end{array}$ & $\begin{array}{c}6 \pm 2.6 / 9.9 \pm \\
5.9 \\
p<0.001\end{array}$ & $\begin{array}{c}3 / 5 \\
p=0.6\end{array}$ \\
\hline $\begin{array}{c}\text { Ni, C.Y. } \\
\quad(11)\end{array}$ & 2013 & $\mathrm{RCT}$ & 80 & 80 & $\begin{array}{l}\text { Primary: complication rate } \\
\text { Secondary: C-reactive protein level ; } \\
\text { LoS ; liver functional status on POD } 5 \text {; } \\
\text { general comfort questionnaire measures }\end{array}$ & $\begin{array}{c}10(12.5 \%) / \\
20(25 \%) \\
p=0.04\end{array}$ & $\begin{array}{c}14(17.5 \%) / \\
17(21 \%) \\
p=0.55\end{array}$ & $\begin{array}{c}6.9 \pm 2.8 / 8.0 \pm \\
3.7 \\
p=0.018\end{array}$ & $\mathrm{NC}$ \\
\hline
\end{tabular}




\section{Articles characteristics}

The characteristics of the included studies are presented in Table and II. 524 patients were included in 4 RCTs: 254 in ERAS group and 270 in traditional care group. In the study by Liang et al [8], it is important to notice that a part of the study was not prospective. Patients were ASA I, II or

III. Within the 4 studies, 2 studied laparoscopic surgery and the 2 other studies concerned open surgery. Procedures were conducted mostly for colorectal liver metastases, hepatocellular carcinoma (HCC) or benign diseases. In the study by Jones et al [9], the 2 groups were not comparable. The ERAS group had more patients with colorectal metastases. Therefore, they received more preoperative neoadjuvant chemotherapy versus traditional care group $(p=0.021)$. In the other studies $[8,10,11]$, groups were similar. ERAS components were described for each study and are presented in Table III. All studies used a similar approach in perioperative management and described discharge criteria by evaluating analgesia, tolerance for solid food and willingness to go home. Of note, "good pain control" was not defined in studies.

\section{Outcomes}

All results are presented in Error! Reference source not found. IV. 
Complications

All studies graded complications according to the Dindo-Clavien classification scored Grade I to V [12]. Liang et al. [8] and Ni et al. [11] found that the morbidity rate, considering all complications (Grade I to V), was significantly lower in the ERAS group whereas He et al. [10] and Jones et al. [9] did not. This difference may be explained by the sample size. Indeed, number of patient range from single to double (from $\mathrm{n}=86$ in He [10] and $\mathrm{n}=$ 91 in Jones [9], up to $n=187$ in Liang [8] and $n=160$ in Ni [11]). Moreover, the complication rate according to the Dindo-Clavien classification was the primary outcome of only one study (Ni et al [11]). An estimation of the sample size was realized before inclusion to perform a power of $80 \%$ for 2-tailed log-rank test. They needed to include 160 patients, 80 in each group, to report $18 \%$ difference between the ERAS group and the TC group in the overall complication rates. Finally, they randomised 80 patients in each group and found a significant difference between ERAS group and TC group (30\% vs $46.3 \%, p=0.03)$. Among all complications, we can notice that significant differences were reported on Grade I Dindo-Clavien classification while number of Grade II to V complications were similar. In the study by Liang et al [8], deep vein thrombosis was significantly lower in ERAS than traditional care group (0 vs 6 event, $p=0.03$ ) whereas in Ni et al, it was nausea and vomiting (7 vs 18 event, $p=0.02)$. In the study by Jones et al [9], grade complication details were not reported. Even if overall complication rate did not reach the statistical significance in this study ( $17 \%$ for ERAS vs $31 \%$ for traditional, $p=0.126$ ), we can notice that liver surgery-specific complication rates were similar (15\% ERAS vs $11 \%$ traditional, $\mathrm{p}=0.612$ ) and total number of general complications was lower in ERAS group (4 vs 20, $\mathrm{p}=0.009$ ).

Length of stay 
All studies reported a significant reduction of postoperative length of stay. Definition of LoS was different in the study by Jones et al [9]. Indeed, LoS included days after eventual readmissions whereas the other studies had the same definition of postoperative LoS: from the day of surgery until the day of discharge. Days of hospitalisation before the surgery were not included in the LoS. We noticed that Jones et al [9] included ASA II patients whereas others studies included patients ASA I and II. Patients were also older than other studies and had open surgery. But despite all, they had the shortest LoS of all studies (in ERAS or TC). Furthermore, length of stay was the primary outcome of the study as well as in He et al [10] and Liang et al [8] studies. None of the 3 studies performed a sample size calculation before inclusions.

\section{Quality of life}

Three studies investigated the quality of life after surgery. He et al [10] primary outcome was a composite including quality of life (QoL) applying the EQ-5D test and length of hospital stay. They found that the QoL after surgery was under the baseline measure in both groups. However one month after surgery, QoL was considerably improved in the ERAS group (median AUC 36.9 versus 35.2, p = 0.04). In the study by Jones et al. [9], QoL was a secondary outcome. They used the same test (EQ-5D) and found similar results. In the study by Ni et al [11], one of the secondary outcome was general comfort questionnaire measures (GCQ). In that study, the mean GCQ measures was higher in the ERAS group than in the TC group $(101.2+/-13$ vs $93.4+/-21.4, P<0.01)$.

\section{Readmission rate}

None of the studies reported a significant difference in terms of readmission. Reasons for readmission were: urinary tract infection for traditional care group, postoperative bile leakage and abdominal collection $(n=2)$ for ERAS group. Liang et al. did not precise reasons for the 8 readmissions. 
The Ni et al study [11] did not considered readmission as an outcome.

Post-operative mortality

None of the studies found a significant difference in mortality. There were only 2 deaths in Jones et al, which were the consequence of postoperative small liver syndrome due to extensive preoperative neoadjuvant chemotherapy. In Ni et al study [11], mortality was not reported.

\section{Discussion}

The aim of this review was to assess the safety and efficacy of ERAS protocols in liver surgery. With 4 studies representing 524 patients, we found that LoS was in favor of ERAS group while readmission and mortality rate were not different than TC. Two studies [8, 11] found lower complication rate in ERAS group while the 2 others $[9,10]$ did not report any significant difference between the 2 groups. Thus, ERAS seems to be safe and efficient for open and laparoscopic liver surgery. Furthermore, He et al [10] analysed quality of life after surgery and established that patients in ERAS group had a higher score at 1 month than traditional care group (median area under the curve respectively: 36.9 versus $35.2, \mathrm{P}=0.04$ ). Several reviews and meta-analysis are available on this subject. Two meta-analysis $[13,14]$ reported a reduced LoS in the ERAS group despite the heterogeneity of the studies $\left(\mathrm{I}^{2}=77 \%\right.$ and $\left.\mathrm{I}^{2}=89 \%\right)$. In these meta-analyses, the complication rate was lower in ERAS group $\left(\mathrm{P}<0.0001, \mathrm{I}^{2}=0 \%\right.$ and $\mathrm{P}<0.0001, \mathrm{I}^{2}=0 \%$ ). Furthermore, as shown by Liang et al [8] and Ni et al [11], the meta-analysis by Li et al [13] found a significant difference not only in Grade I complications (OR $0.55,95 \% \mathrm{Cl}: 0.31-0.98, \mathrm{P}=0.04, \mathrm{I}=0 \%$ ) but also in Grade II to $\mathrm{V}$ complications (OR $0.49,95 \% \mathrm{Cl}$ : $0.32-$ 
$0.76, \mathrm{P}=0.001, \mathrm{I}=0 \%$ ). No statistical difference was shown for readmission rate (OR $1.16,95 \% \mathrm{Cl}: 0.38-3.54, \mathrm{P}=0.08)$. All 4 selected studies reported a reduction in LoS despite applying different ERAS components. Indeed, analgesia regimens were all multimodal but included different techniques (from epidural to morphine PCA or fentanyl transdermal patch). No clear differences in ERAS components can explain the differences in complication rate when comparing the 4 studies. Jones et al applied the most ERAS components when compared with the 3 other studies and did not observe any difference in complication rate. He et al [10] reported lower hospital costs in the ERAS group (7742 $\pm 1200 ¥$ vs. $9470 \pm 1540 ¥, P=$ 0.03). Liang et al. also compared hospitalization costs: $\$ 6871 \pm 2571$ in the ERAS group and $\$ 7948 \pm 3630$ in the control group (P=0.020). On the opposite, Joliat et al. [15] did not find any significant difference in total hospital cost (€38,726 for the ERAS group and €42,356 (26,898) for the preERAS group, $p=0.467)$. A recent meta-analysis [16] found that hospitalization costs were lower in ERAS group $(\mathrm{SMD}=-0.31,95 \% \mathrm{Cl}=-0.47$ to $0.14, P=0.0002$, fixed-effects model: $P=0.53,12=0 \%)$. The heterogeneity of the results and the comparison of costs in different countries/heath system do not allow us to draw any conclusion. More studies with identical evaluation criterion are needed to evaluate the total hospitalization cost for patient in an ERAS clinical pathway.

Our study has limitations. The quality assessment left us with only 4 studies to analyse, one of them (Liang et al [8]) being just partly prospective. Furthermore, patient eligible standards, treatment programmes, number of ERAS elements used and discharge criteria were quite different between studies. Moreover, inclusion of cirrhotic patients in the selected studies was heterogeneous. This is important as cirrhotic patients can develop more complications. In Liang et al study [8], there was a non-statistically significant trend towards more cirrhotic patients in the conventional group, and this could partly explain the higher rate of complications or longer hospital stay. It should also be noted that 3 of the 4 selected articles included Chinese patients introducing potential bias of selection. It is difficult to know the degree of adherence to ERAS elements that was applied by the care team. Finally, nowadays it seems difficult to design a RCT comparing ERAS with a group including no ERAS components. Jones et al [9] minimise that bias by using an independent blinded clinician for the evaluation of discharge criteria. 
In order to homogenise ERAS items in liver surgery, recommendations have been published by Melloul et al. [17] in 2016. Regarding the evidence of the literature about ERAS in liver surgery, they strongly recommended, among others: preoperative counselling and education of patients, no preoperative fasting more than $6 \mathrm{~h}$, antibiotic prophylaxis, minimal invasive approach, no nasogastric tube routinely, maintenance of normothermia during liver resection, eat normal food at postoperative day 1, no routine thoracic epidural analgesia (wound infusion catheter or intrathecal opiates can be good alternatives combined with multimodal analgesia), multimodal approach to postoperative nausea, vomiting and analgesia and target guiding fluid. These components are the same as these recommended in colorectal surgery. Nevertheless, some essential items for colorectal surgery like laparoscopic surgery, early mobilisation, early removal of urinary catheter and no routine drainage of the peritoneal cavity are not actually reported as advisable for liver surgery. The ERAS group recommendations are the only ones published so far. Recommendations from scientific society are needed.

In conclusion, ERAS in hepatic surgery is feasible, safe, efficient and worthwhile for patients. Thereby, recommendations have been established for liver surgery. Nevertheless, additional studies of quality applying strong grade recommendations and evaluating the weak ones are essential to optimise ERAS clinical pathway. 


\section{References}

[1] Kehlet H. Multimodal approach to control postoperative pathophysiology and rehabilitation. Br J Anaesth 1997; 78 : 606-617.

[2] Wu S-J, Xiong X-Z, Lu J, et al. Fast-Track Programs for Liver Surgery: A Meta-Analysis. J Gastrointest Surg Off J Soc Surg Aliment Tract 2015; 19: 1640-1652.

[3] Rehabilitation rapide apres une chirurgie colorectale programmée. SFAR - Société Française d'Anesthésie et de Réanimationhttp://sfar.org/rehabilitation-rapide-apres-une-chirurgie-colorectale-programmee/ (2015, accessed 22 November 2017).

[4] Muehling B, Schelzig $\mathrm{H}$, Steffen $\mathrm{P}$, et al. A prospective randomized trial comparing traditional and fast-track patient care in elective open infrarenal aneurysm repair. World J Surg 2009; 33: 577-585.

[5] Jones EL, Wainwright TW, Foster JD, et al. A systematic review of patient reported outcomes and patient experience in enhanced recovery after orthopaedic surgery. Ann R Coll Surg Engl 2014; 96: 89-94.

[6] Benzoni E, Molaro R, Cedolini C, et al. Liver resection for HCC: analysis of causes and risk factors linked to postoperative complications. Hepatogastroenterology 2007; 54: 186-189.

[7] Karanjia ND, Lordan JT, Fawcett WJ, et al. Survival and recurrence after neo-adjuvant chemotherapy and liver resection for colorectal metastases: a ten year study. Eur J Surg Oncol 2009; 35: 838-843.

[8] Liang X, Ying H, Wang H, et al. Enhanced Recovery Program Versus Traditional Care in Laparoscopic Hepatectomy. Medicine (Baltimore) 2016; 95: e2835.

[9] Jones C, Kelliher L, Dickinson M, et al. Randomized clinical trial on enhanced recovery versus standard care following open liver resection. Br J Surg 2013; 100: 1015-1024. 
[10] He F, Lin X, Xie F, et al. The effect of enhanced recovery program for patients undergoing partial laparoscopic hepatectomy of liver cancer. Clin Transl Oncol Off Publ Fed Span Oncol Soc Natl Cancer Inst Mex 2015; 17: 694-701.

[11] Ni CY, Yang Y, Chang YQ, et al. Fast-track surgery improves postoperative recovery in patients undergoing partial hepatectomy for primary liver cancer: A prospective randomized controlled trial. Eur J Surg Oncol J Eur Soc Surg Oncol Br Assoc Surg Oncol 2013 ; 39: 542-547.

[12] Dindo D, Demartines N, Clavien P-A. Classification of surgical complications: a new proposal with evaluation in a cohort of 6336 patients and results of a survey. Ann Surg 2004; 240: 205-213.

[13] Li L, Chen J, Liu Z, et al. Enhanced recovery program versus traditional care after hepatectomy: A meta-analysis. Medicine (Baltimore) 2017; 96: e8052.

[14] Zhao Y, Qin H, Wu Y, et al. Enhanced recovery after surgery program reduces length of hospital stay and complications in liver resection: A PRISMA-compliant systematic review and meta-analysis of randomized controlled trials. Medicine (Baltimore) 2017; 96 : e7628.

[15] Joliat G-R, Labgaa I, Hübner M, et al. Cost-Benefit Analysis of the Implementation of an Enhanced Recovery Program in Liver Surgery. World J Surg 2016; 40: 2441-2450.

[16] Wang C, Zheng G, Zhang W, et al. Enhanced Recovery after Surgery Programs for Liver Resection: a Meta-analysis. J Gastrointest Surg Off J Soc Surg Aliment Tract 2017; 21: 472-486.

[17] Melloul E, Hübner M, Scott M, et al. Guidelines for Perioperative Care for Liver Surgery: Enhanced Recovery After Surgery (ERAS) Society Recommendations. World J Surg 2016; 40: 2425-2440. 


\section{Legend of the figures:}

Figure 1: PRISMA flow chart

Table I: JADAD composite scale score for each study. Points attribution: 1 point for blinding, appropriate method of blinding, randomization, appropriate method of randomization and description of outputs and withdrawals while attribute -1 point if blinding was inappropriate or if randomization was inappropriate

Table II: Characteristics of the studies: ASA: American Society of Anesthesiologists, ERAS: Enhanced Recovery After Surgery, TC: Traditional Care, HCC: hepatocellular carcinoma.

Table III: Summary of ERAS components. ERAS: Enhanced Recovery After Surgery, NA: Not Available, i.v.: intra venous, ICU: Intensive Care Unit, PCIA: Patient-Controlled Intravenous Analgesia

Table IV: Results of the studies

We wish to confirm that there are no known conflicts of interest associated with this publication and there has been no significant financial support for this work that could have influenced its outcome.

We confirm that the manuscript has been read and approved by all named authors and that there are no other persons who satisfied the criteria for authorship but are not listed. We further confirm that the order of authors listed in the manuscript has been approved by all of us.

We confirm that we have given due consideration to the protection of intellectual property associated with this work and that there are no impediments to publication, including the timing of publication, with respect to intellectual property. In so doing we confirm that we have followed the regulations of our institutions concerning intellectual property.

We further confirm that any aspect of the work covered in this manuscript that has involved either experimental animals or human patients has been 
conducted with the ethical approval of all relevant bodies and that such approvals are acknowledged within the manuscript.

We understand that the Corresponding Author is the sole contact for the Editorial process (including Editorial Manager and direct communications with the office). He/she is responsible for communicating with the other authors about progress, submissions of revisions and final approval of proofs. We confirm that we have provided a current, correct email address which is accessible by the Corresponding Author and which has been configured to accept email from (helene.beloeil@chu-rennes.fr)

Signed by all authors as follows:

Helene Beloeil

Pauline Rouxel 


\section{EX TABLE I}

\begin{tabular}{|c|c|c|c|c|c|c|c|c|c|c|c|c|}
\hline \multirow[t]{2}{*}{ Author } & \multirow[t]{2}{*}{ Year } & \multirow[t]{2}{*}{ JADAD } & \multicolumn{2}{|c|}{$\begin{array}{c}\text { Sample size } \\
(n)\end{array}$} & \multicolumn{2}{|c|}{$\begin{array}{c}\text { Age (years) } \\
\text { Mean } \pm S D(\text { except *) }\end{array}$} & \multicolumn{2}{|c|}{$\begin{array}{c}\text { Gender } M / F \\
(n)\end{array}$} & \multicolumn{2}{|c|}{$\underset{(n)}{\operatorname{ASA} \mathbf{I}, \mathbf{I I}, \mathbf{I I I}}$} & \multirow[t]{2}{*}{$\begin{array}{l}\text { Type of } \\
\text { surgery }\end{array}$} & \multirow{2}{*}{$\begin{array}{c}\begin{array}{c}\text { Patholo } \\
\text { / ber }\end{array} \\
\text { ERAS }\end{array}$} \\
\hline & & & ERAS & $\mathbf{T C}$ & ERAS & TC & ERAS & TC & ERAS & TC & & \\
\hline He, F. (10) & 2015 & 3 & 48 & 38 & $56.3 \pm 16.3$ & $60.4 \pm 20.7$ & $22 / 26$ & $\begin{array}{c}18 / \\
20\end{array}$ & $10,26,3$ & $12,24,2$ & Laparoscopic & $31 / 17$ \\
\hline Jones, C. (9) & 2013 & 3 & 46 & 45 & $\begin{array}{c}64(27- \\
83)^{*}\end{array}$ & $67(27-84)^{*}$ & $31 / 15$ & $\begin{array}{l}23 / \\
22\end{array}$ & $0,43,3$ & $2,38,5$ & Open & $45 / 1$ \\
\hline Liang, X. (8) & 2016 & 2 & 80 & 107 & $53.4 \pm 13.5$ & $55.5 \pm 12.8$ & 37 / 43 & $\begin{array}{l}50 / \\
57\end{array}$ & $35,45, \mathrm{NC}$ & $49,58, \mathrm{NC}$ & Laparoscopic & $51 / 29$ \\
\hline Ni, C.Y. (11) & 2013 & 2 & 80 & 80 & $48.4 \pm 15.6$ & $50.1 \pm 21.8$ & 66 / 14 & $\begin{array}{c}59 / \\
21\end{array}$ & $76,4, \mathrm{NC}$ & $78,2, \mathrm{NC}$ & Open & $80 / 0$ \\
\hline
\end{tabular}

* Median (interquartile range)

NEW TABLE I BECOMING TABLE II 


\section{Characteristics of the studies}

\begin{tabular}{|c|c|c|c|c|c|c|c|c|c|c|c|c|c|c|}
\hline \multirow[t]{2}{*}{ Author } & \multirow[t]{2}{*}{ Year } & \multicolumn{2}{|c|}{$\begin{array}{l}\text { Sample } \\
\text { size }\end{array}$} & \multicolumn{3}{|c|}{$\begin{array}{c}\text { Age (years) } \\
\text { Mean } \pm S D(\text { except } *)\end{array}$} & \multicolumn{4}{|c|}{$\begin{array}{c}\text { Gender M/F } \\
n(\%)\end{array}$} & \multicolumn{4}{|c|}{$\begin{array}{c}\text { ASA I, II, III } \\
n(\%)\end{array}$} \\
\hline & & ERAS & TC & ERA & & TC & ERAS & & TC & & ERAS & & & TC \\
\hline $\mathrm{He}, \mathrm{F} .(10)$ & 2015 & 48 & 38 & $56.3 \pm$ & 16.3 & $60.4 \pm 20.7$ & $22(46 \%) / 26$ & $(54 \%)$ & $18(47 \%) / 2$ & $(53 \%)$ & $10(21 \%), 26(54 \%$ & $.2(4 \%)$ & $12(32 \%)$, & $24(63 \%), 2(5 \%)$ \\
\hline Jones, C. (9) & 2013 & 46 & 45 & $64(27-$ & $83)^{*}$ & $67(27-84)^{*}$ & $22(48 \%) / 15$ & $(33 \%)$ & $23(51 \%) / 2$ & $(49 \%)$ & $0,43(93 \%), 3$ & $(7 \%)$ & $2(4,5 \%), 38$ & $8(84,5 \%), 5(11 \%$ \\
\hline Liang, $X$. (8) & 2016 & 80 & 107 & $53.4 \pm$ & 13.5 & $55.5 \pm 12.8$ & $22(28 \%) / 43$ & $(54 \%)$ & $50(47 \%) / 5$ & $(53 \%)$ & $35(44 \%), 45(5$ & $5 \%), 0$ & $49(46 \%$ & 6), $58(54 \%), 0$ \\
\hline Ni, C.Y. (11) & 2013 & 80 & 80 & $48.4 \pm$ & 15.6 & $50.1 \pm 21.8$ & $22(27,5 \%) / 14$ & $(17,5 \%)$ & $59(74 \%) / 2$ & $(26 \%)$ & $76(95 \%), 4(5$ & ), 0 & $78(97,5$ & $\%), 2(2,5 \%), 0$ \\
\hline \multirow[t]{2}{*}{ Author } & \multirow{2}{*}{\multicolumn{2}{|c|}{$\begin{array}{l}\text { Type of } \\
\text { surgery }\end{array}$}} & \multicolumn{4}{|c|}{ Perioperative blood loss $(m L)$} & \multicolumn{3}{|c|}{$\begin{array}{l}\text { Pathology malign / benign } \\
\mathrm{n}(\%)\end{array}$} & \multirow{2}{*}{\multicolumn{2}{|c|}{$\begin{array}{l}\text { Reasons for liver } \\
\text { resection (malign } \\
\text { pathologies) }\end{array}$}} & \multicolumn{3}{|c|}{$\begin{array}{l}\text { Extent of liver resection } \\
\text { major / minor }{ }^{* *}, \mathrm{n}(\%)\end{array}$} \\
\hline & & & \multicolumn{2}{|c|}{ ERAS } & \multicolumn{2}{|r|}{ TC } & ERAS & \multicolumn{2}{|r|}{ TC } & & & \multicolumn{2}{|r|}{ ERAS } & TC \\
\hline $\mathrm{He}, \mathrm{F} .(10)$ & \multicolumn{2}{|c|}{ Laparoscopic } & \multicolumn{2}{|c|}{$350 \pm 170$} & \multicolumn{2}{|c|}{$338 \pm 190$} & $31(65 \%) / 17(35 \%)$ & \multicolumn{2}{|c|}{$24(63 \%) / 14(37 \%)$} & \multicolumn{2}{|c|}{ HCC, Colorectal Mets } & \multicolumn{2}{|c|}{$0 / 48(100 \%)$} & $0 / 38(100 \%)$ \\
\hline Jones, C. (9) & \multicolumn{2}{|c|}{ Open } & \multicolumn{2}{|c|}{$350(174-900)^{*}$} & \multicolumn{2}{|c|}{$340(150-645)^{*}$} & $45(98 \%) / 1(2 \%)$ & \multicolumn{2}{|c|}{$36(80 \%) / 9(20 \%)$} & \multicolumn{2}{|c|}{ Colorectal Mets, Other Mets } & \multicolumn{2}{|c|}{$21(46 \%) / 25(54 \%)$} & $12(27 \%) / 33(7:$ \\
\hline Liang, $X .(8)$ & \multicolumn{2}{|c|}{ Laparoscopic } & \multicolumn{2}{|c|}{$268.2 \pm 416.0$} & \multicolumn{2}{|c|}{$328.0 \pm 426.2$} & $51(64 \%) / 29(36 \%)$ & \multicolumn{2}{|c|}{$55(51 \%) / 52(49 \%)$} & \multicolumn{2}{|c|}{$\begin{array}{c}\text { HCC, HCC Mets, } \\
\text { Cholangiocarcinoma }\end{array}$} & \multicolumn{2}{|c|}{$17(21 \%) / 63(79 \%)$} & $29(27 \%) / 78(7:$ \\
\hline Ni, C.Y. (11) & \multicolumn{2}{|c|}{ Open } & \multicolumn{2}{|c|}{$313.4 \pm 223.9$} & 358 & $2 \pm 311.7$ & $80(100 \%) / 0$ & 801 & $100 \%) / 0$ & $\mathrm{HCC}$, & olangiocarcinoma & $73(91$ & $\%) / 7(9 \%)$ & $69(86 \%) / 11(1+$ \\
\hline
\end{tabular}

- Median (interquartile range)

** Major resection: $\geq 3$ segments 
Table I: JADAD composite scale score for each study

\section{JADAD Score}

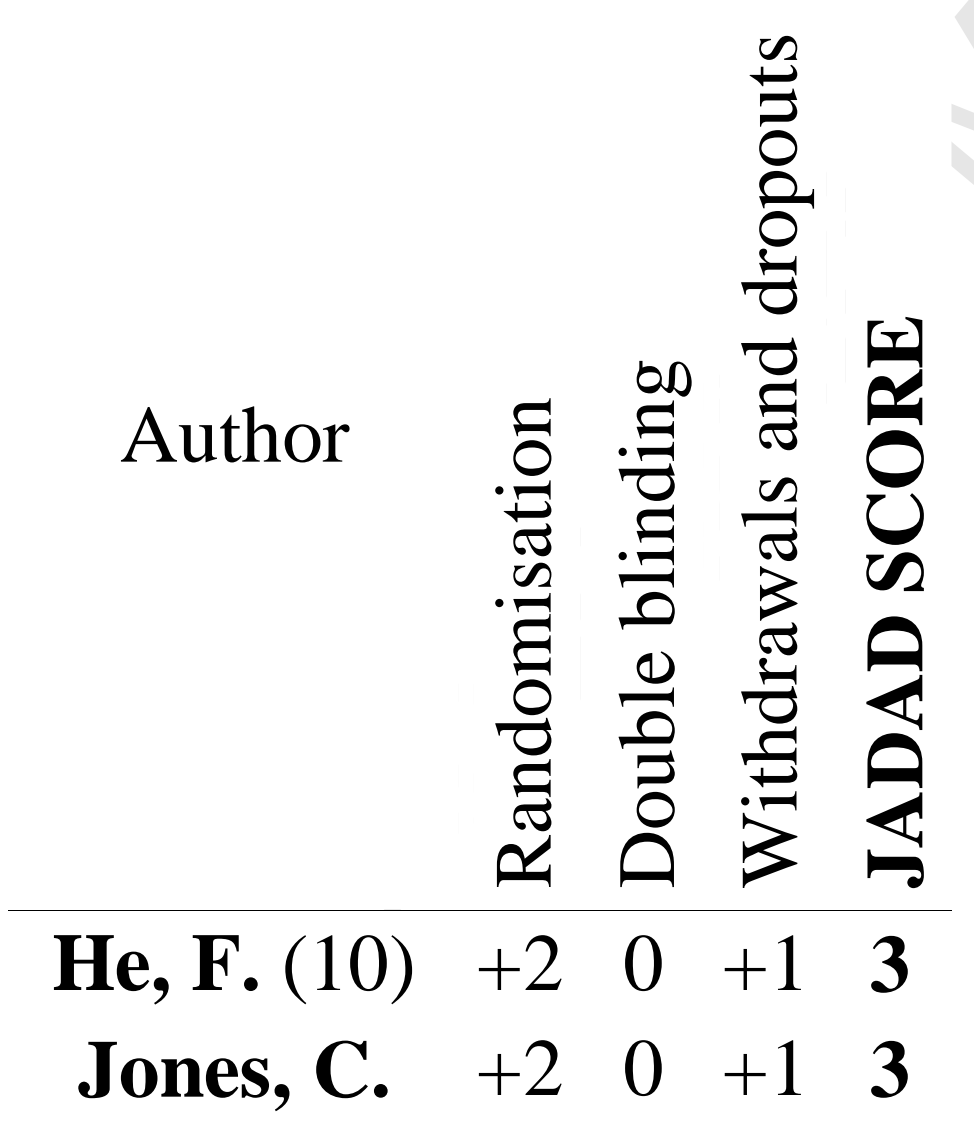


(9)

\section{Liang, $X$.}

(8)

Ni, C.Y.

(11) $\begin{array}{llll}+1 & 0 & 0 & 1\end{array}$

$\begin{array}{llll}+2 & 0 & +1 & 3\end{array}$

\begin{tabular}{|c|c|c|c|c|}
\hline & $\begin{array}{l}\text { He, F. } 2015 \\
(10)\end{array}$ & Jones, C. 2013 (9) & $\begin{array}{c}\text { Liang, X. } 2016 \\
(8)\end{array}$ & Ni, C.Y. 2013 (11) \\
\hline \multicolumn{5}{|l|}{ Preoperative } \\
\hline \multicolumn{5}{|l|}{ Preoperative education or exercise } \\
\hline \multicolumn{5}{|l|}{ Avoid bowel preparation } \\
\hline Avoid preanesthetic medications & $N A$ & & $N A$ & \\
\hline \multicolumn{5}{|l|}{ Carbohydrate drinks up to $2 h$ before } \\
\hline \multicolumn{5}{|l|}{ surgery. } \\
\hline Minimal preoperative fasting (2h) & & $N A$ & $N A$ & $N A$ \\
\hline \multicolumn{5}{|l|}{ Perioperative } \\
\hline \multicolumn{5}{|l|}{ Antibiotic prophylaxis } \\
\hline \multicolumn{5}{|l|}{ Epidural analgesia } \\
\hline \multicolumn{5}{|l|}{ Short-acting i.v. anesthetic agent } \\
\hline \multicolumn{5}{|l|}{ Prevention of hypothermia } \\
\hline \multicolumn{5}{|l|}{ Avoidance of excessive i.v. fluids } \\
\hline \multicolumn{5}{|l|}{ No routine drainage of the peritoneal } \\
\hline No nasogastric tube or early removal & & & & \\
\hline
\end{tabular}


after surgery

\section{Postoperative}

Not sent routinely to the ICU

Early removal of urinary catheter (within the 1st 24h)

Early oral intake

Early mobilization

Early discontinuation of i.v. fluids

Early restoration of normal diet

Glucose control

Nausea and vomiting prophylaxis

Multimodal analgesia

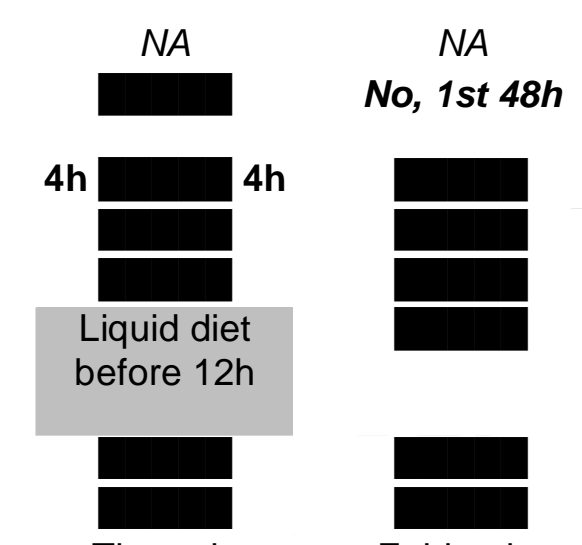

Thoracic epidural
Epidural +

(1g paracetamol + tramadol 50-

$100 \mathrm{mg} / 6 \mathrm{~h}$

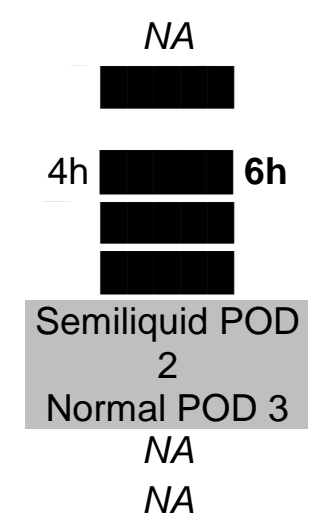

Trocar incision

analgesia + PCIA + 40mg transdermal patch

ParecoxibNa

$/ 12 \mathrm{~h}+/-50 \mathrm{mg}$

tramadol

NA

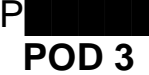

$N A$

$N A$

Epidural or

\section{Discharge criteria}

Normal or decreasing serum bilirubin

Good pain control with oral analgesia only

Tolerance of solid food

No i.v. fluids

Mobile independently or at the preoperative level

Willingness to go home

Normal body temperature

No incision infection
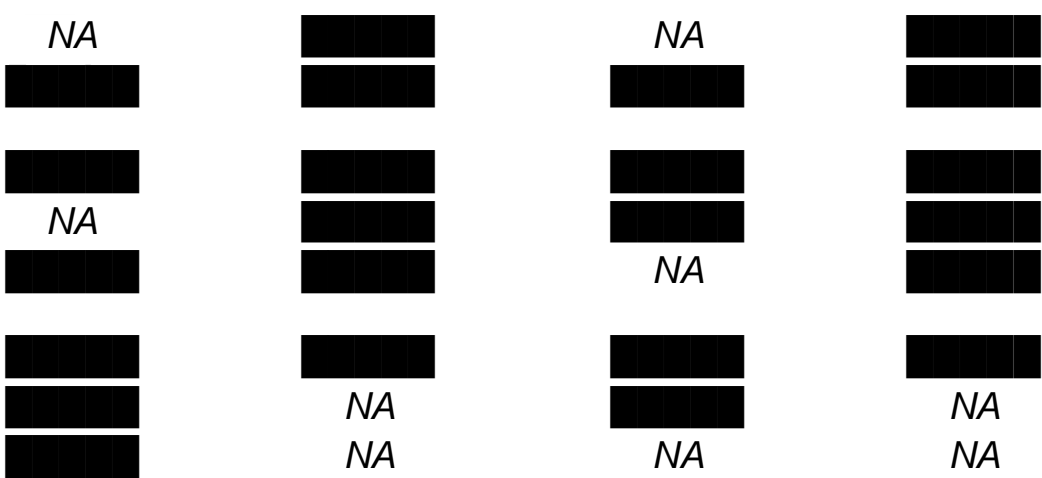

(n)


EX TABLE III 


\begin{tabular}{|c|c|c|c|c|c|c|c|c|c|}
\hline \multirow[t]{2}{*}{ Author } & \multirow[t]{2}{*}{ Year } & \multirow[t]{2}{*}{$\begin{array}{l}\text { Type } \\
\text { of } \\
\text { cases }\end{array}$} & \multicolumn{2}{|c|}{$\begin{array}{l}\text { Nb. of } \\
\text { patients } \\
(n)\end{array}$} & \multirow[t]{2}{*}{ Study endpoints } & \multirow{2}{*}{$\begin{array}{l}\text { Complication } \\
\text { \& morbidity } \\
\text { ERAS / TC }\end{array}$} & \multirow{2}{*}{$\begin{array}{c}\text { Postoperative } \\
\text { length of stay } \\
\text { (days) } \\
\begin{array}{c}\text { Median (interquartile } \\
\text { range) }\end{array} \\
\text { ERAS / TC }\end{array}$} & \multirow{2}{*}{$\begin{array}{l}\text { Readmission } \\
\qquad(n) \\
\text { ERAS / TC }\end{array}$} & \multirow{2}{*}{$\begin{array}{r}\text { Mor } \\
\text { ER } \\
\mathbf{T}\end{array}$} \\
\hline & & & $\begin{array}{c}\text { ERA } \\
\mathbf{S}\end{array}$ & $\mathbf{T C}$ & & & & & \\
\hline He, F. (10) & 2015 & $\mathrm{RCT}$ & 48 & 38 & $\begin{array}{l}\text { Primary: quality of life ; LoS } \\
\text { Secondary: } \% \text { of readmission ; mortality ; } \\
\text { functional recovery ; complication ; hospital } \\
\text { costs ; conversions ; blood loss }\end{array}$ & $\begin{array}{c}7(15 \%) / 6(16 \%) \\
p=0.88\end{array}$ & $\begin{array}{c}6(4-8) / 10(7-15) \\
p=0.04\end{array}$ & $\begin{array}{l}1 / 1 \\
p=1\end{array}$ & $\begin{array}{c}0 \\
p=\end{array}$ \\
\hline $\begin{array}{c}\text { Jones, C. } \\
(9)\end{array}$ & 2013 & $\mathrm{RCT}$ & 46 & 45 & $\begin{array}{l}\text { Primary: LoS } \\
\text { Secondary: Pain score ; morbidity ; } \\
\text { mortality ( } 30 \text { days follow-up) ; volume of } \\
\text { IV fluids ; time to return of : bowel sounds, } \\
\text { flatus, full diet, bowel opening and } \\
\text { mobilization }\end{array}$ & $\begin{array}{l}17 \% / 31 \% \\
p=0.126\end{array}$ & $\begin{array}{c}4(3-5) / 7(6-8) \\
p<0.001\end{array}$ & $\begin{array}{c}2 / 0 \\
p=0.153\end{array}$ & $p=$ \\
\hline$\underset{(8)}{\text { Liang, } \mathbf{X} .}$ & 2016 & $\mathrm{RCT}$ & 80 & 107 & $\begin{array}{l}\text { Primary: LoS ; hospitalization cost } \\
\text { Secondary: resumption of oral intake ; pain } \\
\text { score ; readmissions ; complications }\end{array}$ & $\begin{array}{c}18(22 \%) / 47 \\
(44 \%) \\
p=\mathbf{0 . 0 0 2}\end{array}$ & $\begin{array}{c}6 \pm 2.6 / 9.9 \pm 5.9 \\
\boldsymbol{p}<0.001\end{array}$ & $\begin{array}{c}3 / 5 \\
p=0.6\end{array}$ & $\begin{array}{c}0 \\
p=\end{array}$ \\
\hline $\begin{array}{l}\text { Ni, C.Y. } \\
\quad(11)\end{array}$ & 2013 & $\mathrm{RCT}$ & 80 & 80 & $\begin{array}{l}\text { Primary: complication rate } \\
\text { Secondary: C-reactive protein level ; LoS } \\
\text { liver functional status on POD } 5 ; \text { general } \\
\text { comfort questionnaire measures }\end{array}$ & $\begin{array}{c}24(30 \%) / 37 \\
(46 \%) \\
p=0.03\end{array}$ & $\begin{array}{c}6.9 \pm 2.8 / 8.0 \pm 3.7 \\
\boldsymbol{p}=\mathbf{0 . 0 1 8}\end{array}$ & $\mathrm{NC}$ & $\Lambda$ \\
\hline
\end{tabular}


TABLE III NOW TABLE IV

\section{Results of the studies}

\begin{tabular}{|c|c|c|c|c|c|c|c|c|c|}
\hline \multirow{3}{*}{ Author } & \multirow{3}{*}{ Year } & \multirow{3}{*}{$\begin{array}{l}\text { Type } \\
\text { of } \\
\text { cases }\end{array}$} & \multirow{2}{*}{\multicolumn{2}{|c|}{$\begin{array}{l}\text { Nb. of } \\
\text { patients } \\
(n)\end{array}$}} & \multirow{3}{*}{ Study endpoints } & \multicolumn{2}{|c|}{ Complications } & \multirow{3}{*}{$\begin{array}{l}\text { Postoperative } \\
\text { length of stay } \\
\text { (days) } \\
\text { Median (interquartile } \\
\text { range) } \\
\text { ERAS / TC }\end{array}$} & \multirow{3}{*}{$\begin{array}{l}\text { ReadmissioI } \\
\text { (n) } \\
\text { ERAS / TC }\end{array}$} \\
\hline & & & & & & \multicolumn{2}{|c|}{$\underset{\text { to } V}{\text { Grade I }}$} & & \\
\hline & & & ERAS & TC & & ERAS / TC & ERAS / TC & & \\
\hline $\begin{array}{c}\mathbf{H e}, \mathbf{F} . \\
(10)\end{array}$ & 2015 & $\mathrm{RCT}$ & 48 & 38 & $\begin{array}{l}\text { Primary: quality of life ; LoS } \\
\text { Secondary: \% of readmission ; } \\
\text { mortality; functional recovery } \\
\text { complication ; hospital costs ; } \\
\text { conversions ; blood loss }\end{array}$ & $\begin{array}{l}4(8 \%) / 2 \\
(5 \%) \\
p=\mathrm{NC}\end{array}$ & $\begin{array}{l}3(6 \%) / 4 \\
(10.5 \%) \\
p=\mathrm{NC}\end{array}$ & $\begin{array}{c}6(4-8) / 10(7- \\
15) \\
p=0.04\end{array}$ & $\begin{array}{l}1 / 1 \\
p=1\end{array}$ \\
\hline $\begin{array}{c}\text { Jones, C. } \\
(9)\end{array}$ & 2013 & $\mathrm{RCT}$ & 46 & 45 & $\begin{array}{l}\text { Primary: LoS } \\
\text { Secondary: Pain score ; morbidity ; } \\
\text { mortality ( } 30 \text { days follow-up) ; volume } \\
\text { of IV fluids ; time to return of : bowel } \\
\text { sounds, flatus, full diet, bowel opening } \\
\text { and mobilization }\end{array}$ & $\begin{array}{c}2(4 \%) / 4 \\
(9 \%) \\
p=N C\end{array}$ & $\begin{array}{c}12(26 \%) / \\
24(53 \%) \\
p=N C\end{array}$ & $\begin{array}{c}4(3-5) / 7(6-8) \\
p<0.001\end{array}$ & $\begin{array}{c}2 / 0 \\
p=0.153\end{array}$ \\
\hline $\begin{array}{l}\text { Liang, } \\
\text { X. (8) }\end{array}$ & 2016 & $\mathrm{RCT}$ & 80 & 107 & $\begin{array}{l}\text { Primary: LoS ; hospitalization cost } \\
\text { Secondary: resumption of oral intake } \\
\text { pain score ; readmissions ; } \\
\text { complications }\end{array}$ & $\begin{array}{c}5(6 \%) / 14 \\
(13 \%) \\
p=N C\end{array}$ & $\begin{array}{c}13(16 \%) / 33 \\
(31 \%) \\
p=0.02\end{array}$ & $\begin{array}{c}6 \pm 2.6 / 9.9 \pm \\
5.9 \\
p<0.001\end{array}$ & $\begin{array}{c}3 / 5 \\
p=0.6\end{array}$ \\
\hline $\begin{array}{c}\text { Ni, C.Y. } \\
\text { (11) }\end{array}$ & 2013 & $\mathrm{RCT}$ & 80 & 80 & $\begin{array}{l}\text { Primary: complication rate } \\
\text { Secondary: C-reactive protein level ; } \\
\text { LoS ; liver functional status on POD } 5 \text {; } \\
\text { general comfort questionnaire measures }\end{array}$ & $\begin{array}{c}10(12.5 \%) / \\
20(25 \%) \\
p=0.04\end{array}$ & $\begin{array}{c}14(17.5 \%) / \\
17(21 \%) \\
p=0.55\end{array}$ & $\begin{array}{c}6.9 \pm 2.8 / 8.0 \pm \\
3.7 \\
p=\mathbf{0 . 0 1 8}\end{array}$ & $\mathrm{NC}$ \\
\hline
\end{tabular}


Page 36 of 36 